\title{
SAUDI WAHHABI IMPERIALISM IN PAKISTAN: HISTORY, LEGACY, CONTEMPORARY REPRESENTATIONS AND DEBATES
}

\author{
David Waterman \\ University of La Rochelle \\ Faculty of Literature, Languages, Arts, Social Sciences and Humanities \\ 1, Parvis Fernand Braudel \\ 17024 La Rochelle, France \\ Phone: +33(0)5 46685717 \\ david.waterman@univ-lr.fr
}

Received on 1 May, 2014; accepted on 30 June, 2014

doi:10.13165/SMS-14-6-2-02

\begin{abstract}
Historically, Pakistan has nurtured an interpretation of Islam based on Sufi philosophy, which has a reputation of being more tolerant and open-minded. Recent decades have, however, seen a rise in conservative Islam exported from Saudi Arabia; Sunni Wahhabism has become more common in Pakistan largely due to a sociohistorical context, which includes the 1970s oil crises, the 1979 Iranian revolution as well as the Soviet invasion of Afghanistan. Petrodollars have given the Saudi kingdom the necessary resources to finance Wahhabi imperialism, the Iranian revolution has politicized Shia Muslims (who are seen as a threat by the Sunni), and the Afghan war has resulted in the creation of militarized Islam, supported and funded by the USA and Saudi Arabia. General Zia ul-Haq would then take power in Pakistan and capitalize on Saudi support for the hardline Islamization of the country, a policy which has left a trail of sectarian Sunni/Shia violence in its wake.
\end{abstract}

Keywords: Saudi Arabia, Wahhabi, Sunni, Shia, Pakistan, Zia ul-Haq.

Socialinių mokslų studijos / Societal Studies

(C) Mykolo Romerio universitetas, 2014

(C) Mykolas Romeris University, 2014
ISSN 2029-2244 (online)

http://www.mruni.eu/lt/mokslo_darbai/SMS/ http://www.mruni.eu/en/mokslo_darbai/SMS/ 
Although the Islamic Republic of Pakistan has only existed as such for seventy years or so - about one human lifetime, - the Indus Valley region that would become Pakistan has a centuries-long tradition of cultivating a tolerant, open interpretation of Islam, historically infused with Sufi tradition. Recent decades have, however, seen the rise of conservative Wahhabi Sunni Islam in Pakistan, exported from Saudi Arabia with much success, owing to many factors but especially the 1970 s oil shocks, the 1979 Iranian revolution and the Soviet invasion of Afghanistan in the same year. While Pakistan is currently experiencing many difficulties on many different fronts, hard-line Islam is one of the most serious of its challenges, resulting in much sectarian violence as well as contributing to institutional immobility and stagnation in education, culture and politics, not to mention the situation of women more specifically. Although Wahhabi influence has been present on the Indian subcontinent since the 18th century, the focus of this paper will be contemporary and stress the accelerating fundamentalism in Pakistan since the $1970 \mathrm{~s}^{1}$. This paper gives a brief history of the Wahhabi religious tradition in Saudi Arabia, compared to a very different tradition in Pakistan, and then examines the Saudi imperial project at a precise point in time, beginning in 1977 when Zia ul-Haq took control of Pakistan by force of arms with a mission to "Islamize" society. Then, the author of this paper will consider the legacy, after Zia's death, of this religious imperialism and the current debates, consequences and problems it engenders and how it is represented in the press and in contemporary historical fiction.

The Wahhabi tradition takes its name, as Muhammad Iqbal reminds us, from "the great puritan reformer, Muhammad Ibn' Abd al-Wahhāb, who was born in 1700 ", and although Iqbal recognizes the great reformer's influence, he nevertheless highlights Wahhāb's ambivalence, engendered by his uncritical acceptance of tradition:

"[...] inwardly this movement, too, is conservative in its own fashion. While it rises in revolt against the finality of the schools, and vigorously asserts the right of private judgment, its vision of the past is wholly uncritical, and in matter of law it mainly falls back on the traditions of the Prophet."

Iqbal too was conservative in his own fashion, despite his efforts to harmonize scientific and religious thought which leads to a certain ambivalence in itself; he was

1 See, for example, Charles Allen's article in India Today wherein he reminds us that Shah Waliulla, a reformer who founded India's first Deobandi madrassa in the late 18th century, had already initiated the first 'Wahhabi' revitalization of Islam in India; by the 1820s, his family had further imported 'Arab' elements and made the movement more militant. See "Wahhabism and the Origin of Fear" in India Today, 31 July 2008. My thanks to Thierry di Costanzo for his advice.

2 Iqbal, M. The Reconstruction of Religious Thought in Islam. Ed. M. Saeed Sheikh. Intro. Javed Majeed. Stanford, CA: Stanford University Press, 2013. Originally published in 1930; 1989, p. 121. There is some disagreement regarding Wahhāb's birthdate, some historians giving it as 1115/1703; see Iqbal, p. 200. 
an outspoken foe of the Ahmadi sect, for example, arguing that the Ahmadis must be excluded from the Muslim community in the interests of Muslim solidarity ${ }^{3}$. It is this uncritical, "retrograde" Islam, unchanged since the 18th century, that Saudi Arabia is said by its critics to export, as Thomas Hegghammer summarizes:

"Saudi Arabia occupies a central place in the modern history of militant Islamism. Since the oil boom in the 1970s, the kingdom has promoted its ultraconservative Wahhabi interpretation of Islam across the world. [...] To many in the West, Saudi Arabia is synonymous with, and partly responsible for, the rise of Muslim extremism in the late twentieth and early twenty-first centuries." 4

Even so, this conservative Islam did not originate in Saudi Arabia ${ }^{5}$. Lacroix's work on the history of the Sahwa insurrection suggests that any consideration of modern Saudi Islamism should begin in the 1950s, when exiles of the Muslim Brotherhood began settling in the kingdom; the Brotherhood itself had been founded in Egypt in 1928 by Hasan al-Banna and helped bring Nasser to power in the summer of 1952, for which they were repaid with repression by the military regime ${ }^{6}$. Although they were forbidden from opening a branch of the Brotherhood on Saudi soil, they were nevertheless given wide access to the education system, as Lacroix, citing Lashin Abu Shanab in a 2002 speech, recounts:

"The Muslim Brotherhood - Egyptians and non-Egyptians - played an essential role in the development of the kingdom, particularly in the areas of moral education, general education, and Islamic culture. [...] They played a considerable role in the creation of institutes and universities, and in teaching, writing, and the establishment of educational programs for the children of the kingdom at a time when on one else in Arabia was able to take on that task!"

Thus, the members of the Brotherhood were well-positioned in the 1960s and 1970s, at the time of the "Islamic Awakening", or Sahwa, the social movement among young Saudis which sought to politically "Islamize" a society which had, in the past, separated religion from the domain of politics, a domain controlled by the

3 Citing Naveeda Khan, who interprets Iqbal's anti-Ahmadi position as a "defensive action" necessary to preserve Muslim solidarity, "In trying to show how the needs of modern Islam, of the necessity to set Muslims on the course to self-striving, demanded the expulsion of Ahmadis from the fold of Islam, [Iqbal] argued that this expulsion was not a lapse into medieval inquisitional mode by Muslims. It was instead an entirely contemporary need. [...] Iqbal argues that the historical moment demanded Muslim solidarity in India. [...] It was to be a defensive action, to prevent the disintegration of the Muslim community" (p. 117-118). See Khan, N. Muslim Becoming: Aspiration and Skepticism in Pakistan. Durham and London: Duke University Press, 2012.

4 Hegghammer, T. Jihad in Saudi Arabia: Violence and Pan-Islamism Since 1979. Cambridge: Cambridge University Press, 2010, p. 1-2.

5 Lacroix, S. Awakening Islam: The Politics of Religious Dissent in Contemporary Saudi Arabia. Tr. George Holoch. Cambridge, MA: Harvard University Press, 2011, p. 1.

$6 \quad$ Ibid., p. 3, 38.

$7 \quad$ Ibid., p. 37. 
royal family; Lacroix calls this evolution, largely due to the Brotherhood's influence, a "totalizing conception of Islam". The royal family's reputation in religious circles would be further damaged by the 1979 seizure of the Grand Mosque in Mecca, and the presence - at the royal family's request - of American troops in Saudi Arabia after Saddam Hussein's invasion of Kuwait in $1990^{9}$.

Efforts to modernize Saudi institutions had been underway; indeed, that is one of the reasons why the Muslim Brotherhood was welcomed by King Faisal, as a tool of "Islamic modernization", since the Wahhabi ulema was largely incompetent regarding modernity; Faisal's choice was also political, Muslim solidarity envisioned as a response to Nasser's secular Arab nationalism ${ }^{10}$. Efforts at modernization along Western lines had emerged in the 1950s as well, and had faced opposition in the form of repression in the 1970s. Lacroix suggests that whatever political opposition might have existed beforehand was now reduced to simple "cultural" opposition largely due to the oil boom; referring to Giacomo Luciani's work on allocation states versus production states, Lacroix concludes: "it is unlikely that movements motivated by socioeconomic considerations will arise in [a rentier, or allocation] state, so the only protest movements possible are those related to culture or identity." ${ }^{11}$ Annual revenue from oil in the kingdom was multiplied by seventy between 1970 and 1980, to $\$ 84.466$ billion, and the 1982 recession, with a corresponding fall in revenue - to a low of $\$ 16$ billion in 1986 - left an entire generation of young Saudis asking questions about their own future ${ }^{12}$. The result was an anti-modern backlash in terms of cultural identity, with young Saudis often seeking answers to their questions in conservative Sunni Islam and at the same time working to take the country out of the hands of secularists ${ }^{13}$. In addition to economic frustration, other factors for this "identity shift" include alienation resulting from rapid modernization and anti-American sentiment, as well as the presence of charismatic preachers among the Islamists ${ }^{14}$.

8 Lacroix, S., supra note, 5. Lacroix lists many of the most influential figures who were teaching in Saudi universities, including the Palestinian Brother Abdallah 'Azzam, a leading proponent of Arab jihad in Afghanistan and Osama bin Laden's mentor, and the Egyptian Umar Abd al-Rahman, "the future mufti of the assassins of President Sadat, who came to teach in a Saudi Scientific Institute in the 1970s.” See Lacroix, p. 44-45.

$9 \quad$ Ibid., p. 2.

10 Ibid., p. 42-43; Hegghammer, T., op. cit. 4, p. 17.

11 Lacroix, S., supra note, 5. See also Luciani, G. Allocation vs. Production State: A Theoretical Framework. The Arab State. Ed. Giacomo Luciani. Berkeley: University of California Press, 1990, p. 76.

12 Nyrop, R. Saudi Arabia: A Country Study. 4th Edition. Ed. Richard Nyrop. Washington, DC: Foreign Area Studies, American University, 1984, p. 312; Abir, M. Saudi Arabia: Government, Society, and the Gulf Crisis. London: Routledge, 1993, p. 179. See also Lacroix, S., op. cit. 5, p. 76, 129.

13 Ibid., p. 131.

14 Ibid., p. 5. In terms of economic frustration, Lacroix refers to Joshua Teitelbaum, Holier than Thou (Washington, D.C.: Washington Institute for Near East Policy, 2000, p. 5-7), and, 
The success of the revolution in Iran in 1979 also politicized Islam along sectarian lines, and the Wahhabi hardliners found themselves courted by those in power as a counter-balance to the Shia "threat" in Iran: "They played the role that their predecessors in the Muslim Brotherhood had played in the past against Nasser. They thereby became indispensable to the regime, which offered them an ever-increasing number of opportunities." ${ }^{15}$ As it will be seen later, violence against the Shia minority in Pakistan remains common, and the lack of adequate responses leads one to suspect a certain amount of complicity at the institutional level. Finally, the Soviet invasion of Afghanistan in 1979 created a common cause for Muslims around the world, the jihad funded not only by Saudi Arabia but the United States as well; the high-level support of extremist Islamism in the decade-long war is undoubtedly one of the most serious strategic errors of the twentieth century, a geopolitical blunder with no thought given to the long-term consequences, which are still being felt today. Even in Saudi Arabia, Lacroix reminds us that Wahhabi Islamists were largely nationalist in their objectives, responding with only lukewarm enthusiasm to the call to jihad, even as Saudi conservative Islamism was becoming more political elsewhere around the globe in the recruiting of jihadis, identifying their enemies as both the godless West and non-Sunni Muslims, especially the Shia and Sufi sects ${ }^{16}$. The key figure linking Afghanistan, Saudi Arabia and Pakistan at the time was Abdallah Azzam, a Muslim Brother who has gone down in history as Osama bin Laden's mentor. From Islamabad and then Peshawar, Azzam formally called for global jihad with the publication of his 1984 book, The Defense of Muslim Territories is the First Individual Duty ${ }^{17}$. Although the call to jihad was successful on an international scale, the Wahhabi religious establishment within Saudi Arabia remained skeptical: "the Afghans were considered 'bad Muslims' because they belonged to the Maturidi school (close to the Ash'arite school, which allows some room for reason, earning denunciation from the Wahhabis) in matters of creed, followed the Hanafi school of jurisprudence, and were inclined toward the practice of Sufism." ${ }^{18}$ Hegghammer reminds us that through the early 20th century, non-Wahhabi Muslims were considered non-Muslims in Wahhabi religious thought, an exclusivist position which evolved especially after the

regarding the charismatic religious figures al-'Awda and al-Hawali, see Mamoun, F. Saudi Arabia and the Politics of Dissent.Basingstoke: Macmillan, 1999, p. 61-114. Lacroix goes on to argue that there were of course other factors involved, as the socio-historic context contained many more variables, which can best be appreciated by what he calls the "field concept". See Lacroix, p. 6-7.

15 Lacroix, S., supra note 5, p. 103.

16 Ibid., p. 109, 52.

17 Ibid., p. 110. An English translation, entitled Defense of the Muslim Lands: The First Obligation after Iman, can be found at: www.kalamullah.com/Books/defence.pdf. [accessed on 8-112013].

Ibid., p. 11. 
creation of the World Muslim League in 1962 as an organism for exporting Saudi influence as well as another tool to be deployed against secular Arab nationalism ${ }^{19}$.

The Muslim World League counted members from those sympathetic to the Muslim Brotherhood's cause, including Abu al-'Ala Mawdudi, a Pakistani and founder of the Jamaat-e Islami (JI), a radical Islamist party still active today ${ }^{20}$. Peshawar, because of its location - closer to the Afghan border - was to become the hub of Islamist activity in the 1980s, first as a location for Saudi charities and religious organizations, which allowed the Saudi state to distance itself from official support for the Afghan jihad, even though, Hegghammer contends, "Many of [the Saudi charities] extended logistical and other services to combatants in addition to their humanitarian or missionary activities"21. Weapons destined for Pakistan were sent through Saudi Arabia, with CIA support, and Hegghammer also notes that the Saudi ambassador gave Osama bin Laden logistical support in 1985, moving a bulldozer from Saudi Arabia to Pakistan and then on to a training camp in Afghanistan ${ }^{22}$. This active Pakistani cooperation with Saudi Arabia and the United States is understandable, given the war in Afghanistan, yet is only the tip of the iceberg regarding Saudi influence in Pakistan; the war, in fact, was a convenient excuse and an opportunity for Pakistani leaders to receive billions of dollars of Saudi and US aid, thus providing the necessary resources for one man, General Zia ulHaq, to pursue a program of radical Brotherhood/Wahhabi Islamization of Pakistan, which he could not have accomplished otherwise. Of course, Pakistan was founded in 1947 as an Islamic republic, a homeland for India's Muslims, although its founding father, Mohammad Ali Jinnah - a Shia - was cautious in his approach to the role of Islam within the structure of the new nation, at least if one considers his oft-cited "secularist" speech to the constituent assembly: "You are free; you are free to go to your temples, you are free to go to your mosques or to any other place of worship in this State of Pakistan. You may belong to any religion or caste or creed - that has nothing to do with the business of the State."23 Jinnah's untimely death left Pakistan without its charismatic leader and opened a breach for his successors, both military and civilian and often clearly secularist, to exploit Islam for political purposes: the "modernist" Ayub Khan, for example, had to replace "Islamic" in the official name of the Republic of Pakistan, and Z. A. Bhutto, not known for his religious devotion, declared sharia law and also excluded the Ahmadi sect in cold (and often erroneous)

19 Hegghammer, T., op. cit. 4, p. 17. See also Lacroix, S., op. cit. 5, p. 42.

20 Lacroix, S., supra note 5, p. 42.

21 Hegghammer, T., op. cit. 4, p. 26.

22 Ibid., p. 27.

23 Muhammad Ali Jinnah's First Presidential Address to the Constituent Assembly of Pakistan. August 11, 1947 [interactive]. [accessed on 10-11-2013]. <http://www.columbia.edu/itc/ mealac/pritchett/00islamlinks/txt_jinnah_assembly_1947.html $>$. For an in-depth examination of Jinnah's supposed secularism, see Karim, S. Secular Jinnah and Pakistan: What the Nation Doesn't Know. Dublin: CheckPoint Press, 2010. 
political calculations ${ }^{24}$. But it was Zia who, well beyond simple political maneuvering, embarked on a mission to Islamize Pakistan along Wahhabi lines.

As it has been said, Pakistan - or the territory that would become Pakistan had for centuries been a Muslim land which enjoyed relative tolerance between sects and benefitted from the influence of a more mystical, popular form of Islam, Sufism, including its reverence of saints ${ }^{25}$. Ayesha Jalal suggests that Pakistan's reputation as a "relatively liberal and modern Muslim state" continued until the early 1970s, when the Pakistani civil war of 1971 and the loss of the eastern wing created the conditions, even before Zia's accession to power, for an anti-secular backlash and Saudi incursion:

"Unaccustomed to learning from history and more comfortable with myths of an imagined past, Pakistanis were susceptible to the Islamist charge that the ruling elite's lack of religiosity had caused the country's disintegration. [...] Lines of credit were sought from friendly Arab states, softening the blows of the global oil shock for cash-starved Pakistan. The global reassertion of Islam on the back of Arab petro-dollars won the admiration of Pakistan's rising middle classes, who sought to emulate the Saudi variant of Wahabi Islam." ${ }^{\prime 26}$

Zulfikar Ali Bhutto became, in spite of concessions to the religious parties, the symbol of Pakistan's decadence and would be deposed in a coup d'état, then executed, by Zia ul-Haq, the transition from one Islamic order to another summarized by Kamila Shamsie:

"Prior to Zia, Pakistan's leaders had often raised the banner of Islam as a politically expedient tool, but, apart from Bhutto's banning of the Ahmadis for reasons both political and personal, they had always ensured that Islam remained at best a cosmetic gloss to the functioning of the state. With Zia, that old order was to be turned firmly on its head. [...] Zia's Islam became Pakistan's Islam." ${ }^{27}$ Unlike Bhutto, Zia was personally very religious and had made several trips to Mecca, and after his seizure of power he was received by the Saudis as a head of state; formal contact with Saudi Arabia was initiated almost immediately after the coup

24 Gaborieau, M. Islam and Politics. A History of Pakistan and Its Origins. Ed. Christophe Jaffrelot. London: Anthem Press, 2004, p. 246-247.

25 Mohammad-Arif, A. The Diversity of Islam. A History of Pakistan and Its Origins. Ed. Christophe Jaffrelot. London: Anthem Press, 2004, p. 231.

26 Jalal, A. The Past as Present. Pakistan: Beyond the Crisis State. Ed. Maleeha Lodhi. London: Hurst \& Company, 2011, p. 14-15.

27 Shamsie, K. Offence: The Muslim Case. Manifestos for the 21st Century. London; New York; Calcutta: Seagull Books, 2009, p. 46-48. By "politically expedient tool" Shamsie is referring to the deployment of Islam as a means of creating national unity and identity within an extremely diverse country wherein people often see themselves as Bengali or Sindhi or Punjabi, in other words, as a means "to undercut provincial dissent". See Shamsie, K. Offence: The Muslim Case, p. 34. It is also true that Islam was being used to create a binary opposition with Hindu, thus perpetuating a strategy of unification by defining a common enemy, in this case - India. 
d'état by then-Chief Martial Law Administrator General Mohammed Zia-ul-Haq ${ }^{28}$. In a chapter entitled "The Diversity of Islam", Aminah Mohammad-Arif insists that Zia's Saudi-inspired Islamization (and more precisely, Zia's proximity to the Jamaat-i Islami party founded by Maududi, as it has been mentioned) resulted in the blatant promotion of Sunni Wahhabi Islam and the demonization of the Shia minority; what had been largely doctrinal disputes between the two sects now became more overtly violent $^{29}$. Zia's first confrontation with the Shia was related to the payment of alms, or zakât; while compulsory for the Sunni, such payment was optional for the Shia, and Zia's attempt to compel the Shia to pay such alms was met with violent resistance which, according to Mohammad-Arif, not only undermined Zia's authority and angered the military, but increased worries that the Iranian revolution was directly politicizing Shia activity in Pakistan ${ }^{30}$. Reacting to this fear of the Iranian "contagion" spreading to Pakistan, Zia embarked on a project to strengthen Sunni educational institutions, notably through the creation of madrasas, or Koranic schools linked to the major Sunni schools of thought and often funded by Saudi Arabia; the exponential multiplication of madrasas is one of the major elements of Zia's Islamization policies, the effects of which are still being felt today ${ }^{31}$. Zia also pushed for extremist reforms in the judicial and political arenas, many of which are still in effect, as Shamsie reminds us:

"Lashing, amputation, stoning to death-all in public. Most offensive of all to Muslims for whom theirs was a religion of justice, the Hudood Ordinances allowed for rape victims to be tried for adultery and stoned to death. [...] In 1983, the Islamic Law of Evidence decreed that in legal matters the evidence of two women is equal to that of one man. [...] This was also the year that, under

28 Ali, M. General Mohammed Zia-ul-Haq's Visit to Muslim Countries. Pakistan Horizon. 1977, 3/4(30): 103-107; Pakistan Institute of International Affairs, p. 103 [interactive]. [accessed on 25-05-2013].<http://www.jstor.org/stable/41393337>.

29 Mohammad-Arif, A. supra note 25, p. 233.

$30 \quad$ Ibid.

31 Ibid., p. 233-234. It is impossible to determine how many madrassas are operating in Pakistan. Mohammad-Arif and others report that at the moment of Pakistan's founding, there were 137 madrassas (234), whereas current numbers range from 14,000 to 24,000 registered Koranic schools; unregistered schools abound as well. According to a January 2013 article in Developyst, Karachi alone counts 736 unregistered madrassas. See Madrassas in Pakistan [interactive]. [accessed on 21-01-2014]. <http://www.developyst.org/>. It must be remembered, however, that the vast majority of parents send their children to madrassas for economic, rather than religious, reasons; quoting a 2003 report from the Social Policy and Development Center, Islamopedia Online reports that $89 \%$ of students cite economic reasons for their enrollment in madrassas. See Madrassas and Militancy [interactive]. [accessed on 21-01-2014]. <http://www. islamopediaonline.org/country-profile/pakistan/islam-and-education-system/madrassasand-militancy $>$. Although one of the effects of madrassa education still being felt today is the extremist ideology being inculcated in a relatively small percentage of the schools, in the author's view, the far greater demographic time bomb is related to the fact that the madrassas generally do not provide Pakistan's burgeoning youth population with the necessary skills to find gainful employment. 
the Hudood Ordinances, Safia Bibi, a blind 13-year-old girl who was raped but couldn't identify her attackers, was found guilty of adultery and sentenced to imprisonment, a fine and a public lashing." ${ }^{32}$

The religious parties, especially the JI, could not believe their good fortune. After thirty years on the margin, they now had access to power at the highest level; Qadeer reports that in 1978, fully two-thirds of Zia's ministers were appointed from the ranks of the religious parties ${ }^{33}$. For the first time since Partition, instead of a secular government which deployed Islam as a political tool, the roles were now reversed: "Islamists had their opportunity to utilize the state's authority to push their social and cultural agenda. [...] the drive for an Islamic order came to mean changing culture and reorganizing society." 34

The Soviet invasion of Afghanistan and the resulting decade-long war would reinforce the role of the madrassas as the first step in the process of recruiting and training fighters for the jihad, the holy war, as would Zia's open door policy to international networks of what Olivier Roy calls "Islamic brigades", many of which were associated with the Muslim Brothers, a policy encouraged and funded by both the United States and Saudi Arabia, a policy which would have disastrous effects long after the Soviet withdrawal in 1988:

"[the Afghan jihadi] were heavily subsidized by the Gulf States, especially Saudi Arabia. This Saudi largesse also took the form of training grants, gradually introducing a much more 'Wahhabi' influence which was quite hostile towards local religious traditions, both learned and popular. This was the setting for the development of the movement which became known as the Taliban." ${ }^{35}$

The militarization of Islam and the US and Saudi support of international Islamic brigades has created unintended and far-reaching consequences around the globe as these holy warriors have remobilized in other regions after the defeat of the Soviet Union. The paradox is striking; Muslim warriors whose mission was to defeat godless communist invaders are still active in Afghanistan and Pakistan and elsewhere, yet most of their victims are in fact other Muslims, victims of the ongoing tensions between Sunni and Shia. Saudi Arabia's imperial project in Pakistan continues unabated, fanning the flames of sectarian violence with petrodollars; Zia's legacy, rather than uniting Pakistan under the banner of Wahhabi Islam, is instead one of almost daily killing between Muslims themselves, widely reported in the Pakistani press and an important element of contemporary Pakistani historical fiction.

32 Shamsie, K., supra note 27, p. 48-49.

33 Qadeer, M. A. Pakistan: Social and Cultural Transformations in a Muslim Nation. London and New York: Routledge, 2006, p. 166.

34 Ibid., p. 166-167.

35 Roy, O. Islam and Foreign Policy: Central Asia and the Arab-Persian World. A History of Pakistan and Its Origins. Ed. Christophe Jaffrelot. London: Anthem Press, 2004, p. 140. 
A 2012 article from Press TV, entitled "Carnage of Shia Muslims in Pakistan", deplores the current situation, qualified as nearly genocidal, before tracing the historical roots of the conflict: "With thousands of Shia Muslims killed over the past few years in Pakistan and over 400 murdered in recent months, the killings have practically amounted to genocide." Longstanding institutional complicity regarding anti-Shia violence is taken to be self-evident:

"That the Shia mass murders have continued over the years with no legal and judiciary source or law enforcement agencies having sought to put an end to these brutalities indicates that these acts are but to be considered as part of a systematic and organized plot prodigiously funded and ingeniously engineered by internal and external forces..."36

Salami then goes further back in time and pinpoints Zia ul-Haq as the man "who made it a state policy to fund and arm Wahhabi groups in the 1980s. It was during those years when he technically institutionalized violence by unleashing Sipah-e Sahaba fundamentalists on Shia-populated regions, ushering in a new age of violence and mayhem." ${ }^{37}$ The most significant episode of this institutionalized violence, the Gilgit massacre of May 1988, is then detailed by Salami, who reminds us that Pakistani intelligence agencies were also monitoring Shia activities in the aftermath of the Iranian revolution ${ }^{38}$. The recent leaks of diplomatic cables have only confirmed what journalists and historians have long been saying, according to Ishaan Tharoor:

"A December 2009 secret cable signed by Secretary of State Hillary Clinton called Saudi Arabia 'a critical source of terrorist funding.' And that had a direct bearing on Pakistan, since it alleged that much of the financial backing for jihadist organizations in Pakistan continued to originate in Saudi Arabia, despite Riyadh's efforts to cut down on private donations to Sunni militant groups abroad." ${ }^{39}$

36 Salami, I. Carnage of Shia Muslims in Paakistan. Press TV. 6 September, 2012 [interactive]. [accessed on 04-06-2013]. <http://www.presstv.ir/detail/2012/09/05/260017/genocide-of-shiamuslims-in-pakistan/>..

Ibid.

38 Ibid. Citing the authors, "In 1988, Zia ul-Haq dispatched a huge army of 80,000 extremists to Shia-populated Gilgit region to annihilate the Shias. Adjacent villages such as Jalalabad, Bonji, Darot, Jaglot, Pari, and Manawar were razed to the ground and over 700 Shia Muslims were massacred. According to a Herald report 'In May 1988, low-intensity political rivalry and sectarian tension ignited into full-scale carnage as thousands of armed tribesmen from outside Gilgit district invaded Gilgit along the Karakoram Highway. Nobody stopped them. They destroyed crops and houses, lynched and burnt people to death in the villages around Gilgit town. The number of dead and injured was put in the hundreds. But numbers alone tell nothing of the savagery of the invading hordes and the chilling impact it has left on these peaceful valleys."' See Salami, I. Camage of Shia Muslims in Pakistan. Press TV. 6 September, 2012 [interactive]. [accessed on 04-06-2013]. <http://www.presstv.ir/detail/2012/09/05/260017/ genocide-of-shia-muslims-in-pakistan/>.

39 Tharoor, I. WikiLeaks: The Saudis' Close but Strained Ties with Pakistan. Time. 6 December, 2010 [interactive]. [accessed on 04-06-2013]. <http://content.time.com/time/world/ article/0,8599,2035347,00.html\#ixzz17NnxjLVZ>. 
Other leaked US cables further incriminate Saudi Arabia in the funding of extremist Sunni groups operating within Pakistan, such as al-Qaeda, the Taliban and Lashkar-e-Taiba [which] "probably raise millions of dollars each year in Saudi Arabia" ${ }^{40}$. Pervez Hoodbhoy's 2009 article, "Is Pakistan Emulating Saudi Arabia?", gives an overview of Zia's legacy of Islamization and arrives at a very pessimistic conclusion:

"For three decades, deep tectonic forces have been silently tearing Pakistan away from the Indian subcontinent and driving it towards the Arabian peninsula. This continental drift is not physical but cultural, driven by a belief that Pakistan must exchange its South Asian identity for an Arab-Muslim one. Grain by grain, the desert sands of Saudi Arabia are replacing the rich soil that had nurtured a magnificent Muslim culture in India for a thousand years. [...] Now a stern, unyielding version of Islam (Wahhabism) is replacing the kinder, gentler Islam of the Sufis and saints who had walked on this land for hundreds of years." ${ }^{41}$

Hoodbhoy blames Zia in the first instance, citing the Afghan war and other factors that have been already mentioned and goes on to accuse every succeeding government of cowardice regarding their refusal to significantly overhaul the Pakistani education system, especially its madrassas which supplied "cannon fodder" during the war and today turn out unemployed students who reproduce "a grim and humourless Saudi-inspired revivalist movement that frowns on any and every expression of joy and pleasure"42. Hoodbhoy especially deplores the degraded condition of women, including women from the upper classes who had, for a time, been spared the constraints of their poorer sisters; speaking of his own experience as a university professor, Hoodbhoy laments: "The Saudi-isation of a once-vibrant Pakistani culture continues at a relentless pace. [...] Many of my veiled female students have largely become silent note-takers, are increasingly timid and seem less inclined to ask questions or take part in discussions."

Despite other constraints, Pakistan is fortunate in having a functioning free press, a press which does not shy away from controversial issues, as some of the preceding examples show, both from within and without Pakistan. The Saudi imperial project has also been treated in other forms of nonfiction works, such as essays, theses and the like, and indeed some of Pakistan's most notable fiction writers also write for the press and in other nonfiction media. Kamila Shamsie's Offence: The Muslim Case is a prime example. Offence charts the rise of Muslim extremism, and while Shamsie is of course extremely critical of Zia and his legacy, she reminds us that it was in fact Z. A. Bhutto who opened the door to Saudi influence and thus made Zia's Islamization program that much easier:

40 Tharoor, I., supra note 39.

41 Hoodbhoy, P. Is Pakistan Emulating Saudi Arabia? Haq's Musings [blog]. 27 January, 2009 [interactive]. [accessed on 25-05-2013]. <http://www.riazhaq.com/2009/01/is-pakistanbecoming-saudi-arabia.html>.

Ibid. 
"Bhutto was seeking to extend his influence as a regional leader. In the wake of the 1973 oil crisis, he recognized the oil-producing Arab nations as major power players to whom he wanted to ally himself; his hosting of the Second Islamic Summit was the most visible sign of this. But this new regional association meant allying himself with Saudi Arabia and its ultra-hardline, puritanical Wahabi version of Islam, closely tied to Maududi's JI."44

As it has been already mentioned, the Afghan war brought billions of dollars of US and Saudi aid to Pakistan, giving Zia the necessary means to implement his extremist interpretation of Islam, and leaving an unwanted legacy, unwanted at least by the majority of Pakistani Muslims: "A new generation of Pakistanis was growing up in a world in which the tentacles of Zia's Islam were everywhere." ${ }^{45}$ Mohsin Hamid too, in a chapter entitled "Why Pakistan will Survive", discusses the question of Pakistani identity from many different perspectives, one being how an average Pakistani might relate to Zia's legacy:

"Similarly, if the test of being a Pakistani is that I would like our country to look more like what Zia-ul-Haq had in mind - in other words, a country where you could happily live your life according to any interpretation of Islam so long as it was his interpretation of Islam - then I fail again. I don't want my government imposing its view of religion on me. [...] So I support the idea that Pakistan should be a place where Muslims are free to practice their religion according to their own conscience, and where religious minorities are free to do the same."46

Zia's Islamization policy and its catastrophic consequences on the Muslims of the Indus Valley has made its way into contemporary fictional representations as well; many of the current generation of Pakistani writers whose work can easily be qualified as historical fiction have incorporated Zia's legacy into their accounts. They are, after all, the generation that was born in Zia's shadow. While the most direct, albeit brief, reference to the Saudi connection is found in H. M. Naqvi's Home Boy, wherein one of the characters laments the cloud of suspicion that hovers over Pakistanis in the wake of September 11th, reminding the reader that the attackers were, in fact, "a bunch of crazy Saudi bastards" 47 , a more extended treatment of US and Saudi support for Zia is Mohammed Hanif's A Case of Exploding Mangoes. Hanifs novel is a fictionalized account of Zia's final days as Pakistan's president and finally his death in a mysterious plane crash, and presents Zia as a religious zealot bent on imposing his Saudi-inspired interpretation of Islam on the entire country. During his first meeting with his Generals after the coup d'état, Zia berates his audience for their lack of religious conviction - not to mention their inability to understand Arabic -

44 Shamsie, K., supra note 27, p. 42-43.

45 Ibid., p. 55.

46 Hamid, M. Why Pakistan will Survive. Pakistan: Beyond the Crisis State. Ed. Maleeha Lodhi. London: Hurst \& Company, 2011, p. 38-39.

Naqvi, H. M. Home Boy. New York: Shaye Areheart Books, 2009, p. 146. 
and makes it clear that conservative Islam will no longer simply function as a political tool but as official State policy:

"The generals who had called Zia a mullah behind his back felt ashamed at having underestimated him; not only was he a mullah, he was a mullah whose understanding of religion didn't go beyond parroting what he had heard from the next mullah. A mullah without a beard, a mullah in a four-star general's uniform, a mullah with the instincts of a corrupt tax inspector [...] In the name of God, God was exiled from the land and replaced by the one and only Allah who, General Zia convinced himself, spoke only through him." ${ }^{38}$

Zia's direct link with Saudi Arabia is further made explicit in the novel, for example, when Zia thinks to himself: "He wouldn't mind being remembered as Caliph Omar the Second"49, or in the scene recounting Zia's visit to Mecca, a visit which overwhelms Zia but when seen from the perspective of his security chief becomes a parody:

"There were no flashes of divine light, no thunder, the walls of the room were black and without a single inscription. And if it hadn't been for General Zia's choked voice seeking forgiveness, it would have been a quiet room full of stale air. Allah's house was a dark, empty room. ${ }^{\text {"50 }}$

US involvement is highlighted as well, with appearances by Ambassador Arnold Raphael, US Secretary of State George Schultz and CIA Operations Director Bill Casey, not to mention Osama bin Laden' arrival as a guest at the Embassy barbecue ${ }^{51}$. Other contemporary Pakistani novels, while not explicitly mentioning a Saudi connection, nevertheless make the Zia legacy an important background for the setting; a few of them could be mentioned, including Kamila Shamsie's In the City by the Sea, wherein a decidedly Zia-like military dictator has imprisoned his main political rival and cast a pall over the once-vibrant city, while plots to depose him are hatched, or Nadeem Aslam's The Wasted Vigil, set during the Afghan war during the Zia era, underscoring the damage done not only by the Soviet invaders, but by the hardliners of Islam, as well ${ }^{52}$.

Zia's legacy, and by extension the Saudi-supported Islamization of Pakistan of the late 1970s and 1980s, has left deep scars on Pakistan, and, as it has been seen, historians, journalists and novelists have not shied away from condemning Zia as an agent of Saudi imperialism in the political and cultural fabric of Pakistan. Although Zia was killed, quite possibly assassinated, in 1988, Saudi incursion into Pakistan's affairs continues unabated, often in the form of Sunni versus Shia violence. An article entitled "Carnage of Shia Muslims in Pakistan" from Press TV, deploring not only

48 Hanif, M. A Case of Exploding Mangoes. London: Jonathan Cape, 2008, p. 33-34.

49 Ibid., p. 221.

50 Ibid., p. 157.

51 Ibid., p. 207.

52 Shamsie, K. In the City by the Sea. London; New York: Bloomsbury, 1998; Aslam, N. The Wasted Vigil. New York: Knopf, 2008. 
the murders but the lack of institutional response, has already been mentioned; Kamila Shamsie makes a similar point in a 2013 article in The Guardian, entitled "In Pakistan, There's no Answer to Terror: Pakistan's Government and Military alike are Silent on who is Promoting the Murder of Shias in Baluchistan". Shamsie says that "It's symbolic really - Shias are murdered and no one who wants to protest can get anywhere near the president, whose silence can be heard well past the roadblocks." 53 A 2013 article in Dawn, "Smokers' Corner: Petro Games", denounces the terrorist attacks against the Hazara Shia community in Quetta and the general refusal to ask difficult questions: "These questions contain nothing new. It's just that most media personnel and politicians in Pakistan have found it hard to ask them. Mainly because they involve an awkward inquiry into the role of some rich, oil producing Arab monarchies in propping up and funding militant Sunni outfits and terror groups in Pakistan." ${ }^{54}$ Rumors that Saudi Arabia has funded Pakistan's nuclear weapons program also seem to be well-founded, at least if one gauges by the virulent denials of Pakistan's Foreign Office to the contrary ${ }^{55}$. Frédéric Bobin, writing for Le Monde from Karachi just before the elections in May, calls the Sunni-Shia rivalry one of the future Prime Minister's biggest challenges. He goes further, citing the opposition's assertion that Nawaz Sharif's Muslim League has in fact supported anti-Shia activities. In an interview with Allama Abbas Kumaili, director of the Jaffaria Alliance [Shia] Bobin quotes him as saying "An anti-Shia genocide is happening in Pakistan", although ultimately Saudi Arabia is to blame: "The Saudis have financed these extremist groups [Lashkar-e-Jhangvi] with the goal of imposing a Wahhabi State in Pakistan" (author's translation $)^{56}$. However, from time to time, there is a glimmer of hope; an October 2013 article in Dawn, "A Sensible Call: Haj Sermon", congratulates the Saudi grand mufti regarding his Haj sermon, "in which the senior cleric called for shunning sectarianism and condemned terrorism, which was much-needed and timely. The symbolic importance of the event cannot be overlooked, as the religious leader spoke to around 1.5 million believers present at Mount Arafat for the largest gathering of Muslims on earth. ${ }^{57}$ Contemporary Saudi imperialism in Pakistan has functioned on such a grand scale largely due to Saudi foreign aid at a time when Pakistan is dependent on such aid, yet such funding always comes with strings attached; the solution is to cut the strings. Pakistan must concentrate on strengthening its

53 Shamsie, K. In Pakistan, There's no Answer to Terror. 19 February, 2013 [interactive]. [accessed on 14-02-2014]. <http://www.theguardian.com/commentisfree/2013/feb/19/pakistan-terrormurder-shias-baluchistan>.

54 Paracha, N. F. Smokers' Corner: Petro Games. Dawn. 24 February, 2013 [interactive]. [accessed on 04-04-2013]. <http://www.dawn.com/news/788269/smokers-corner-petro-games>.

55 Pakistan Denis Reports Saudis Funded Nuclear Program. Dawn [interactive]. [accessed on 14-04-2014]. <http://www.dawn.com/news/1054796/pakistan-denies-reports-saudis-fundednuclear-program $>$.

56 Bobin, F. La rivalité sunnites-chiites au Pakistan, un des défis du future premier ministre. Le Monde. 11 May, 2013, p. 4.

57 A Sensible Call: Haj Sermon. Dawn. 16 October, 2013 [interactive]. [accessed on 17-10-2013]. 
institutions - poor primary education, for example, is a demographic time bomb waiting to explode - and do everything necessary to end economic dependence on the US and Saudi Arabia: economic development, education leading to employment, a fair and functional tax code. Only then will Pakistan be able to go its own way, and while not all Pakistanis agree what that way should be, their destiny is certainly one of South Asian cultural heritage rather than Saudi Arabian, as Asad Badruddin suggests:

"While religion comes from the same source, it is up to different countries and peoples on how to interpret it to enrich their lives. That is why the Islam practiced in Saudi Arabia is different from the one practiced in most of Pakistan. The role of religion (in all of its cultural, spiritual, non-denominational and ritual manifestations) will remain in society. What is important is for thinkers to channel it into a force that is creative and not destructive, inclusive and pluralistic, not one that imposes its will on the unwilling." 58

Most Pakistanis know this, of course, and many are working to make it happen. Pakistan is home to dynamic universities, a free press and a vibrant literary milieu; these are some of the forums which are necessary to resist Zia's legacy and Saudi (and American) influence, to denounce sectarian violence and ultimately to reclaim Pakistan's South Asian Islamic heritage.

\section{References}

A Sensible Call: Haj Sermon. Dawn. 16 October, 2013 [interactive]. [accessed on 17-10-2013]. <http://www.dawn. com/news/1049971/a-sensible-callhaj-sermon $>$.

Abir, M. Saudi Arabia: Government, Society, and the Gulf Crisis. London: Routledge, 1993.

Ali, M. General Mohammed Zia-ul-Haq's Visit to Muslim Countries. Pakistan Horizon. 1977, 3/4(30): 103-107. Pakistan Institute of International Affairs [interactive]. [accessed on 25-05-2013]. <http://www.jstor.org/ stable/41393337>.

Allen, C. Wahhabism and the Origin of Fear. India Today. 31 July, 2008 [interactive]. [accessed on 10-02-
2014]. <http://indiatoday.intoday.in/ story/Wahhabism+and+the+origin+of + fear/1/12339.html $>$.

Aslam, N. The Wasted Vigil. New York: Knopf, 2008.

Badruddin, A. A Muslim Majority Indus Valley Civilization? Dawn. 22 June, 2012 [interactive]. [accessed on 0404-2013]. <http://www.dawn.com/ news/728611/a-muslim-majorityindus-valley-civilization $>$.

Bobin, F. La rivalité sunnites-chiites au Pakistan, un des défis du future premierministre. Le Monde. 11 May, 2013, p. 4.

Gaborieau, M. Islam and Politics. A History of Pakistan and Its Origins. Ed. 
Christophe Jaffrelot. London: Anthem Press, 2004, p. 237-251.

Hamid, M. Why Pakistan will Survive. Pakistan: Beyond the Crisis State. Ed. Maleeha Lodhi. London: Hurst \& Company, 2011, p. 35-43.

Hanif, M. A Case of Exploding Mangoes. London: Jonathan Cape, 2008.

Hegghammer, T. Jihad in Saudi Arabia: Violence and Pan-Islamism Since 1979.

Cambridge: Cambridge University Press, 2010.

Hoodbhoy, P. Is Pakistan Emulating Saudi Arabia? Haq's Musings [blog]. 27 January, 2009 [interactive]. [accessed on 25-05-2013]. <http://www.riazhaq. com/2009/01/is-pakistan-becomingsaudi-arabia.html>.

Iqbal, M. The Reconstruction of Religious Thought in Islam. Ed. M. Saeed Sheikh. Intro. Javed Majeed. Stanford, CA: Stanford University Press, 2013. Originally published in 1930; 1989.

Jalal, A. The Past as Present. Pakistan: Beyond the Crisis State. Ed. Maleeha Lodhi. London: Hurst \& Company, 2011, p. 7-20.

Jinnah, M. A. Muhammad Ali Jinnah's First Presidential Address to the Constituent Assembly of Pakistan. August 11, 1947 [interactive]. [accessed on 10-11-2013]. <http:// www.columbia.edu/itc/mealac/ pritchett/00islamlinks/txt_jinnah_ assembly_1947.html>.

Khan, N. Muslim Becoming: Aspiration and Skepticism in Pakistan. Durham and London: Duke University Press, 2012.

Lacroix, S. Awakening Islam: The Politics of Religious Dissent in Contemporary Saudi Arabia. Tr. George Holoch. Cambridge, MA: Harvard University Press, 2011.
Luciani, G. Allocation vs. Production State: A Theoretical Framework. The Arab State. Ed. Giacomo Luciani. Berkeley: University of California Press, 1990, p. 65-84.

Mohammad-Arif, A. The Diversity of Islam. A History of Pakistan and Its Origins. Ed. Christophe Jaffrelot. London: Anthem Press, 2004, p. 223-236.

Naqvi, H. M. Home Boy. New York: Shaye Areheart Books, 2009.

Nyrop, R. Saudi Arabia: A Country Study. 4th Edition. Ed. Richard Nyrop. Washington, DC: Foreign Area Studies, American University, 1984.

Pakistan Denies Reports Saudis Funded Nuclear Program. Dawn. 7 November, 2013 [interactive]. [accessed on 0811-2013]. <http://www.dawn.com/ news/1054796/pakistan-denies-reportssaudis-funded-nuclear-program $>$.

Paracha, N. F. Smokers' Corner: Petro Games. Dawn. 24 February, 2013 [interactive]. [accessed on 04-04-2013]. $<$ http://www.dawn.com/news/788269/ smokers-corner-petro-games $>$.

Qadeer, M. A. Pakistan: Social and Cultural Transformations in a Muslim Nation. London and New York: Routledge, 2006.

Roy, O. Islam and Foreign Policy: Central Asia and the Arab-Persian World. A History of Pakistan and Its Origins. Ed. Christophe Jaffrelot. London: Anthem Press, 2004, p. 134-147.

Salami, I. Carnage of Shia Muslims in Pakistan. Press TV. 6 September, 2012 [interactive]. [accessed on 04-062013]. <http://www.presstv.ir/detail/ 2012/09/05/260017/genocide-of-shiamuslims-in-pakistan/>.

Shamsie, K. In Pakistan, There's no Answer to Terror. 19 February, 2013 [interactive]. [accessed on 14-022014]. <http://www.theguardian.com/ 
commentisfree/2013/feb/19/pakistanterror-murder-shias-baluchistan $>$.

Shamsie, K. In the City by the Sea. London;

New York: Bloomsbury, 1998.

Shamsie, K. Offence: The Muslim Case.

Manifestos for the 21st Century.

London; New York; Calcutta: Seagull

Books, 2009.
Tharoor, I. WikiLeaks: The Saudis' Close but Strained Ties with Pakistan. Time. 6 December, 2010 [interactive]. [accessed on 04-06-2013]. <http:// content.time.com/time/world/article/ 0,8599,2035347,00.html\#ixzz17Nnxj LVZ>.

\title{
SAUDO ARABIJOS VAHABISTŲ IMPERIALIZMAS PAKISTANE: ISTORIJA, PAVELDAS, DABARTINÉ SITUACIJA IR DEBATAI
}

\author{
David Waterman
}

La Rošelès universitetas, Prancūzija

Santrauka. Istoriškai taip susikloste, kad Pakistanas puoseleja islamo interpretacija, kylančia iš sufizmo filosofijos, garséjančios savo nuosaikumu ir atvirumu. Pastaraisiais dešimtmečiais iš Saudo Arabijos perkeliamas konservatyvusis islamas; sunitu vahabizmas isigali Pakistane didžia dalimi dèl susiklosčiusio socioistorinio konteksto, apimančio aštuntojo dešimtmečio naftos krizes, 1979 metu Irano revoliuciją ir sovietu isiveržima i Afganistaną. Naftos doleriai suteikè Saudo Arabijos Karalystei pakankamai lèšu remti vahabistu imperializma, Irano revoliucija suteike šiitams (sunitai juos laiko grèsme) politini statusą, o Afganistano karas sudre salygas formuotis kariniam islamui, kuri remia ir finansuoja JAV ir Saudo Arabija. Generolas Zia ul Haqas ketina perimti Pakistano valdžia ir Saudo Arabijos paramos dèka šalyje įves konservatyvųji islamą. Ši politine kryptis kursto sunitu ir šiitų konfrontacijos išpuolius.

Reikšminiai žodžiai: Saudo Arabija, vahabistai, sunitai, šiitai, Pakistanas, Zia ul Haqas.

David Waterman, La Rošelès universitetas, Prancūzija, profesorius. Mokslinių tyrimų kryptys: angliakalbio pasaulio kultūros ir literatūra, Pakistano kultūra.

David Waterman, University of La Rochelle, France, Professor. Research interests: cultures and literatures of the English speaking world, Pakistan culture. 